\title{
Infestasi Cacing Usus dan Faktor-Faktor yang Mempengaruhinya pada Anak yang Tinggal di Daerah Aliran Sungai Siak Kelurahan Pesisir Kecamatan Lima Puluh Pekanbaru
}

\author{
Yolazenia $^{1}$, Suri Dwi Lesmana ${ }^{2}$, Lilly Haslinda ${ }^{2}$
}

\begin{abstract}
Children living around river have higher risk to get helminthes infection. The aim of this study was to determine the prevalence and intensity of helminthes infection and its risk factors for children living around Siak River in Kelurahan Pesisir, Kecamatan Limapuluh, Pekanbaru. A cross-sectional study conducted in September to November 2008, and 65 children participated. Stool were examined using the Kato-Katz technique and the intensity of infections was categorized into: light, moderate, or heavy. The parent of children was asked to fill the questionnaire. We found that $36,9 \%$ subjects were infected by intestinal helminthes. The most common infection was A.lumbricoides and T.trichiura. Most of the subjects had light intensity of infection. There were no correlations between the habits of using river as: source of drinking water, place to defecate, place to take a bath and brush teeth, place to wash vegetables and kitchen tools, and the flood with helminthes infection.
\end{abstract}

Keywords: helminthes infection, children, Siak River, risk factors

Infestasi cacing masih merupakan masalah kesehatan di dunia, khususnya di negara-negara berkembang. Dilaporkan terdapat sekitar 1,5 milyar kasus infestasi cacing di dunia. ${ }^{1}$ Penyakit cacing usus terutama yang ditularkan melalui tanah (Soil transmitted helminthes) seperti Ascaris lumbricoides, Trichuris trichiura dan cacing tambang masih merupakan penyakit rakyat dengan prevalensi yang cukup tinggi terutama pada masyarakat sosial ekonomi rendah di pedesaan di Indonesia yang sangat erat hubungannya dengan keadaan sosial-ekonomi, kebersihan diri dan lingkungan. Infestasi cacing usus ini dapat mengenai semua umur dengan prevalensi tertinggi terdapat pada anak-anak. ${ }^{2}$

Anak usia sekolah dasar (SD) merupakan salah satu kelompok yang berisiko tinggi menderita penyakit ini. Penyakit ini sering ditemukan secara tunggal maupun campuran yang dapat menyebabkan gangguan gizi, anemia, gangguan pertumbuhan dan tingkat kecerdasan. Tingkat pengaruhnya

\footnotetext{
Penulis untuk korespondensi: Bagian Parasitologi FK Universitas Riau. Jl.Diponegoro No.1, Pekanbaru.

Email:yolazenia@yahoo.com

2 Bagian Parasitologi FK Universitas Riau
}

bergantung kepada berat ringannya infeksi, macam cacing, serta endemik tidaknya daerah pemukiman. ${ }^{3,4}$

Prevalensi kecacingan ini sangat bervariasi dari satu daerah ke daerah lain, tergantung dari beberapa faktor antara lain : daerah penelitian (desa atau kota, kumuh, dan lain-lain), kelompok umur yang diperiksa, teknik pemeriksaan, kebiasaan penduduk setempat (tempat buang air besar, cuci tangan sebelum makan, tidak beralas kaki, dan lain-lain), dan pekerjaan penduduk. ${ }^{2,5}$

Beberapa hasil survei cacingan yang dilakukan pada anak SD di daerah kumuh pada 1986-1991 menunjukkan hasil sebesar 60-80\% siswa terinfestasi. ${ }^{6}$ Hasil survei prevalensi cacingan pada tahun 2004 pada 10 propinsi, ditemukan daerah yang paling tinggi terinfestasi cacing adalah BangkaBelitung sebesar 73,03\%. Di Riau ditemukan angka infestasi sebesar 51,93\% dengan angka masingmasing cacing yaitu Ascaris lumbricoides 40\%, Trichiuris trichiura $29,82 \%$ dan cacing tambang $6,67 \%$. $^{7}$

Penyakit cacingan sendiri jarang menyebabkan kematian. Namun pada keadaan kronis pada anak dapat menyebabkan kekurangan gizi yang berakibat 
menurunnya daya tahan tubuh dan akhirnya menimbulkan gangguan tumbuh kembang anak khususnya pada anak usia sekolah dan keadaan ini akan berakibat buruk pada kemampuannya dalam mengikuti pelajaran di sekolah. ${ }^{8}$

Manusia mendapat infestasi cacing usus bila tertelan telur infektif untuk Ascaris lumbricoides dan Trichiuris trichiura, atau larva filariform menembus kulit untuk cacing tambang. Telur cacing bisa tertelan bersama makanan seperti sayuran. Faktor utama dalam pencemaran cacing usus pada sayuran adalah air. Hal tersebut kemungkinan disebabkan oleh pola hidup kurang higienis antara lain cara pencucian sayuran; dikombinasi kebiasaan penduduk makan lalapan mentah, memungkinkan terjadinya infeksi melalui lalapan tersebut. Padatnya penduduk dan terbatasnya lahan mengakibatkan penggunaan sungai sebagai tempat buang air besar di samping kegiatan-kegiatan lain yang berhubungan dengan penggunaan air (mandi, cuci perabot, dan sebagainya). Hal ini menyebabkan sungai mempunyai risiko sebagai sumber pencemaran telur cacing usus. ${ }^{5,9}$

Sungai Siak merupakan sungai utama yang mengalir di Pekanbaru dan tepiannya juga dipakai sebagai hunian penduduk. Salah satu wilayah di Pekanbaru yang dilewati sungai Siak ini adalah Kelurahan Pesisir, Kecamatan Lima Puluh yang letaknya relatif dekat dari pusat kota. Meskipun begitu, sebagian penduduk yang tinggal di tepian Sungai Siak ini masih memanfaatkan sungai tersebut sebagai sarana mandi cuci kakus (MCK). Selain itu, penduduk yang tinggal di sekitar Sungai Siak ini rawan terkena banjir bila musim hujan tiba akibat luapan air sungai. Hal-hal tersebut merupakan risiko untuk terjadinya cacingan pada masyarakat. Dalam penelitian ini penulis ingin mengetahui kasus infestasi cacing usus dan faktor-faktor yang mempengaruhinya pada penduduk yang tinggal di daerah aliran Sungai Siak di Kelurahan Pesisir, Kecamatan Lima Puluh, Pekanbaru.

\section{METODE}

Penelitian ini merupakan studi cross-sectional yang dilakukan pada bulan Agustus - November 2008. Populasi yang menjadi subjek dalam penelitian ini adalah seluruh anak usia 6-13 tahun (usia sekolah dasar) yang tinggal di daerah aliran
Sungai Siak di Kelurahan Pesisir, Kecamatan Lima Puluh, Pekanbaru. Sampel dipilih secara consecutive sampling yang memenuhi kriteria inklusi yaitu: hadir saat pengarahan penelitian, menerima pot tinja dan kuesioner setelah pemberian pengarahan dan menyerahkan kembali pot tinja yang sudah diisi tinja. Sedangkan kriteria ekslusinya yaitu: tinja yang diperiksa tidak mencukupi, dan makan obat cacing 1 bulan yang lalu.

Data yang diambil adalah data primer dari pemeriksaan tinja dan kuesioner. Pemeriksaan tinja dilakukan dengan mikroskopik dengan cara KatoKatz. Pemeriksaan tinja dilakukan di Laboratorium Parasitologi Fakultas Kedokteran Universitas Riau. Hasilnya diidentifikasi sesuai dengan nama dan jumlah telur cacing yang ditemukan. Intensitas infestasi ditentukan oleh banyaknya telur/gram tinja sesuai kriteria Departemen Kesehatan (Depkes). Untuk Ascaris lumbricoides (ringan 1 - 4.999, sedang 5000 - 49.999, berat e"50.000), Trichuris trichiura (ringan 1 - 999, sedang 1000 - 9999, berat e" 10.000) ; dan cacing tambang (ringan 1 1.999, sedang 2000 - 3999, berat e" 4000). ${ }^{6}$ Pada infestasi campuran, intensitas infestasi tergantung pada cacing yang lebih dominan. ${ }^{3}$

Kuesioner berisi pertanyaan mengenai hal-hal menyangkut faktor-faktor yang mempengaruhi kejadian infestasi cacing usus di daerah aliran sungai yaitu kebiasaan menggunakan sungai sebagai: sumber air minum, tempat buang air besar, tempat mandi dan gosok gigi, mencuci sayur/lalapan, mencuci alat masak, dan terjadinya banjir secara rutin tiap tahun.

Data yang terkumpul diolah dengan komputer menggunakan program SPSS 17.0. Analisis data dilakukan secara univariat dan bivariat. Data disajikan dalam bentuk narasi dan tabel distribusi frekuensi. Untuk melihat hubungan antara faktor risiko dengan kasus cacingan digunakan uji Fisher's Exact disebabkan semua variabel yang diteliti mempunyai Expected value < 5, dengan derajat kepercayaan $95 \%(\mathrm{p}<0,05)$.

\section{HASIL}

Subjek pada penelitian ini berjumlah 65 orang anak yang terdiri dari laki-laki 30 orang $(46,2 \%)$ dan perempuan 35 orang $(53,8 \%)$, dengan rata-rata 
umur 9,37 $\pm 2,23$ tahun. Berdasarkan pemeriksaan tinja yang dilakukan pada subjek didapatkan jumlah kasus infestasi cacing usus pada 24 orang $(36,9 \%)$ yang terdiri dari infestasi tunggal dan infestasi campuran. Sebagian besar dari subjek yang terinfestasi mengalami infestasi campuran dari
Ascaris lumbricoides dan Trichuris trichiura sebanyak 10 kasus $(41,67 \%)$, diikuti dengan infestasi tunggal Ascaris lumbricoides pada 8 kasus (33,33\%), Trichuris trichiura pada 6 kasus (25\%), dan tidak ditemukan adanya infestasi cacing tambang (Tabel 1).

Tabel 1. Distribusi frekuensi infestasi cacing usus menurut jenis cacing pada anak yang tinggal di daerah aliran Sungai Siak, Kelurahan Pesisir, Kecamatan Lima Puluh Pekanbaru tahun 2008

\begin{tabular}{ccc}
\hline Jenis Infestasi & $\mathrm{N}$ & $\%$ \\
Ascaris Lumbricoides $(A l)$ & 8 & 33,33 \\
Trichuris trichiura $(\mathrm{Tt})$ & 6 & 25 \\
Cacing tambang $(\mathrm{Ct})$ & 0 & 0 \\
$A l+T t$ & 10 & 41,67 \\
$A l+\mathrm{Ct}$ & 0 & 0 \\
$T t+\mathrm{Ct}$ & 0 & 0 \\
$A l+T t+\mathrm{Ct}$ & 0 & 0 \\
Total & $\mathbf{2 4}$ & $\mathbf{1 0 0}$ \\
\hline
\end{tabular}

Tabel 2. Distribusi frekuensi intensitas infestasi cacing usus pada anak yang tinggal di daerah aliran Sungai Siak, Kelurahan Pesisir, Kecamatan Lima Puluh Pekanbaru tahun 2008

\begin{tabular}{lccc}
\hline & Intensitas Infesta $\mathbf{i}$ & N & \% \\
\hline Ringan & 20 & 83,33 \\
Sedang & & 4 & 16,67 \\
Berat & Total & 0 & 0 \\
\hline & & $\mathbf{2 4}$ & $\mathbf{1 0 0}$ \\
\hline
\end{tabular}

Intensitas infestasi sebagian besar subjek yang terinfestasi cacing tergolong dalam intensitas ringan
(83,33\%), diikuti sedang (16,67\%), dan tidak ada yang ditemukan dengan intensitas berat (Tabel 2).

Tabel 3. Pengaruh beberapa faktor risiko terhadap kejadian infestasi cacing usus pada anak yang tinggal di daerah aliran Sungai Siak, Kelurahan Pesisir, Kecamatan Lima Puluh Pekanbaru tahun 2008

\begin{tabular}{|c|c|c|c|c|c|c|c|}
\hline \multirow[t]{2}{*}{ No. } & \multirow[t]{2}{*}{ Faktor risiko } & \multicolumn{2}{|c|}{$\begin{array}{c}\text { Infestasi } \\
\text { cacing positif }\end{array}$} & \multicolumn{2}{|c|}{$\begin{array}{c}\text { Infestasi } \\
\text { cacing negatif }\end{array}$} & \multirow[t]{2}{*}{ Total } & \multirow[t]{2}{*}{$\begin{array}{c}\text { Nilai } \\
\text { p }\end{array}$} \\
\hline & & $\mathrm{N}$ & $\%$ & $\mathrm{~N}$ & $\%$ & & \\
\hline \multirow[t]{3}{*}{1.} & $\begin{array}{l}\text { Sungai sebagai sumber air } \\
\text { minum }\end{array}$ & & & & & & \\
\hline & - Ya & 0 & 0 & 0 & 0 & 0 & - \\
\hline & - Tidak & 24 & 36,9 & 41 & 63,1 & 65 & \\
\hline
\end{tabular}


2. Sungai sebagai tempat

buang air besar

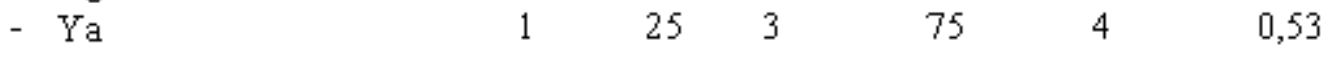

$\begin{array}{llllll}\text { - Tidak } & 23 & 37,7 & 38 & 62,3 & 61\end{array}$

3. Sungai sebagai tempat mandi dan sikat gigi

$\begin{array}{lcccccc}\text { - Ya } & 0 & 0 & 3 & 100 & 3 & 0,24 \\ \text { - Tidak } & 24 & 38,7 & 38 & 61,3 & 62 & \end{array}$

\begin{tabular}{|c|c|c|c|c|c|c|c|}
\hline \multirow[t]{3}{*}{4.} & $\begin{array}{l}\text { Sungai sebagai sumber air } \\
\text { cuci sayur/lalapan }\end{array}$ & & & & & & \multirow{3}{*}{0,63} \\
\hline & - Ya & 0 & 0 & 1 & 100 & 1 & \\
\hline & - Tidak & 24 & 37,5 & 40 & 62,5 & 64 & \\
\hline \multirow[t]{3}{*}{5.} & $\begin{array}{l}\text { Sungai sebagai sumber air } \\
\text { cuci alat masak }\end{array}$ & & & & & & \multirow{3}{*}{0,69} \\
\hline & - Ya & 1 & 33,3 & 2 & 66,7 & 3 & \\
\hline & - Tidak & 23 & 37,1 & 39 & 62,9 & 62 & \\
\hline \multirow[t]{2}{*}{6.} & Banjir rutin tiap tahun & & & & & & \multirow[b]{2}{*}{0,45} \\
\hline & $\begin{array}{l}\text { - Ya } \\
\text { - Tidak }\end{array}$ & $\begin{array}{l}14 \\
10\end{array}$ & $\begin{array}{l}38,9 \\
34,5\end{array}$ & $\begin{array}{l}22 \\
19\end{array}$ & $\begin{array}{l}61,1 \\
65,5\end{array}$ & $\begin{array}{l}36 \\
29\end{array}$ & \\
\hline
\end{tabular}

Berdasarkan Tabel 3 dapat dilihat bahwa semua subjek tidak menggunakan sungai sebagai sumber air minum sehingga tidak bisa dilakukan uji statistik untuk melihat hubungan antara sungai sebagai sumber air minum dengan kejadian infestasi cacing. Subjek yang menggunakan sungai sebagai tempat buang air besar ada 4 orang, dan tidak terdapat hubungan yang bermakna antara sungai sebagai tempat buang air besar dengan kejadian infestasi cacing $(\mathrm{p}=0,53)$. Sungai sebagai tempat mandi dan sikat gigi hanya ditemukan pada 3 orang subjek, dan tidak terdapat hubungan yang bermakna antara sungai sebagai tempat mandi dan sikat gigi dengan kejadian infestasi cacing $(\mathrm{p}=0,24)$.

Sungai sebagai sumber air untuk mencuci sayur/ lalapan hanya detemukan pada 1 subjek, dan tidak terdapat hubungan yang bermakna antara penggunaan sungai sebagai sumber air mencuci sayur/lalapan dengan kejadian infestasi cacing $(\mathrm{p}=0,63)$. Subjek yang menggunakan sungai sebagai sumber air mencuci alat masak ada 3 orang, dan tidak terdapat hubungan yang bermakna antara sungai sebagai sumber air cuci alat masak dengan kejadian infestasi cacing $(\mathrm{p}=0,69)$. Banjir rutin tiap tahun dialami oleh 36 subjek, dimana subjek yang terinfestasi cacing mengalami banjir berjumlah 14 orang $(38,9 \%)$ lebih sedikit dibanding subjek yang terinfestasi tapi tidak mengalami banjir yaitu 22 orang $(61,1 \%)$. Tidak terdapat hubungan bermakna antara subjek yang mengalami banjir rutin dengan kejadian infestasi cacing $(\mathrm{p}=0,45)$.

\section{PEMBAHASAN}

Angka infestasi cacing usus ini $(36,9 \%)$ lebih tinggi dibandingkan angka nasional berdasarkan survei morbiditas cacingan tahun 2004 yaitu sebesar $30,35 \%,{ }^{7}$ dan penelitian pada anak SD Negeri 034 di Kelurahan Sri Meranti, Kecamatan Rumbai yang juga terletak di daerah aliran Sungai Siak yang menemukan angka kejadian kasus infestasi cacing khususnya T.trichiura sebesar $14,44 \% .{ }^{10}$ Beberapa penelitian lain yang dilakukan di Provinsi Riau menunjukkan persentase yang berbeda-beda. Lembaga Swadaya Masyarakat (LSM) Mercy Corp yang melakukan survei cacingan pada siswa SD di Riau pada tahun 2007 menemukan 47,59\% siswa SD menderita cacingan. ${ }^{11}$ Sedangkan penelitian yang dilakukan Herison yang berlokasi di daerah aliran Sungai Rokan, menemukan 69,34\% murid SDN 027 Labuhan Tangga Besar Kecamatan Bangko Kabupaten Rokan Hilir terinfestasi cacing. ${ }^{12}$

Prevalensi cacingan ini sangat bervariasi dari satu daerah ke daerah lain, tergantung dari beberapa faktor antara lain : daerah penelitian (desa atau kota, kumuh, dan lain-lain), kelompok umur yang diperiksa, teknik pemeriksaan, kebiasaan penduduk 
setempat (tempat buang air besar, cuci tangan sebelum makan, tidak beralas kaki, dan lain-lain), dan pekerjaan penduduk. Mengingat lokasi daerah penelitian ini adalah daerah aliran sungai dimana masyarakat sekitarnya sering mengalami banjir sehingga berisiko tinggi mendapat cacingan bila belum memiliki prilaku hidup sehat. Pada penelitian ini ditemukan $63,1 \%$ dari anak usia SD tidak terinfestasi cacing. Hal ini mungkin disebabkan karena sudah adanya kesadaran pada sebagian masyarakat untuk berprilaku hidup sehat. Selain itu Kelurahan Pesisir terletak dekat dari pusat kota dan hanya sedikit masyarakatnya yang benar-benar tinggal di tepian Sungai Siak. Meskipun begitu, kita tetap harus mewaspadai angka kejadian kasus cacingan yang 36,9\% karena angka ini masih jauh di atas tujuan pengendalian cacingan Depkes yaitu menurunkan prevalensi cacingan menjadi $<10 \%{ }^{6}$

Dari subjek yang terinfestasi cacing ditemukan sebagian besar mengalami infestasi campuran dari Ascaris lumbricoides dan Trichuris trichiura (41,67\%), diikuti dengan infestasi tunggal Ascaris lumbricoides (33,33\%), dan Trichuris trichiura (25\%). Herison tahun 2007 juga menemukan hal yang sama, di mana infestasi campuran dari Ascaris lumbricoides dan Trichuris trichiura paling banyak ditemukan, diikuti dengan infestasi tunggal Ascaris lumbricoides dan Trichuris trichiura. ${ }^{11}$ Ascaris lumbricoides dan Trichuris trichiura sering ditemukan secara bersamaan disebabkan karena cara infestasi kedua cacing tersebut sama-sama dengan cara tertelan telur infektif dan habitat kedua cacing ini terdapat pada jenis tanah yang sama yaitu tanah liat. Sedangkan infestasi Ascaris lumbricoides adalah jenis yang paling banyak dijumpai ini disebabkan karena jumlah telur yang dihasilkannya lebih banyak dari jenis cacing yang lain sehingga memungkinkan untuk cacing ini berkembang sangat baik. $^{5}$

Intensitas infestasi sebagian besar subjek yang terinfestasi cacing tergolong dalam intensitas ringan $(83,33 \%)$,diikuti sedang $(16,67 \%)$, dan tidak ada yang ditemukan dengan intensitas berat (Tabel 2). Hal ini sama dengan yang ditemukan Herison dan Dinkes kota Banjar dimana sebagian besar kasus berada dalam intensitas ringan. ${ }^{12,13} \mathrm{Hal}$ ini mungkin berhubungan dengan sistem imunologis karena infestasi cacing ini biasanya bersifat kronis, sehingga sudah terbentuk antibodi spesifik terhadap infestasi cacing, disamping kemungkinan juga sebagian subjek sudah pernah mendapat obat cacing tapi tidak teratur. ${ }^{14}$
Walaupun daerah penelitian ini berlokasi di sepanjang Sungai Siak, ternyata hanya sebagian kecil masyarakatnya yang masih menggunakan sungai sebagai tempat aktivitas sehari-hari, seperti mandi, mencuci, buang air besar, dan lain-lain; yaitu hanya sekitar 4,6\% dari total subjek. Dari hasil uji statistik ternyata tidak ditemukan hubungan yang bermakna antara penggunaan sungai sebagai sumber air minum, tempat buang air besar, tempat mandi dan gosok gigi, sumber air mencuci sayur/lalapan dan mencuci alat masak, dengan kejadian infestasi cacing usus. Hal ini mungkin disebabkan karena lokasi daerah ini yaitu Kelurahan Pesisir berada di pusat kota menyebabkan masyarakat memperoleh kemudahan untuk mendapatkan informasi tentang pemanfaatan air bersih dan sehat, serta penggunaan jamban. Selain itu hanya sedikit masyarakat yang bertempat tinggal benar-benar di pinggiran Sungai Siak karena sebagian digunakan sebagai tempat usaha seperti bengkel, rumah makan, dan lain-lain. Hal ini berbeda dengan yang ditemukan Suwarni et al pada penduduk di sepanjang Sungai Ciliwung didapatkan bahwa penggunaan air sungai untuk mandi dan gosok gigi, mencuci perabot dapur, makan lalapan, dan buang air besar menunjang dalam meningkatnya penularan cacing usus. ${ }^{9}$

Sebagian besar subjek $(55,4 \%)$ umumnya mengalami banjir rutin tiap tahun. Banjir ini sering terjadi pada musim hujan akibat luapan air Sungai Siak. Walaupun begitu tidak ditemukan hubungan yang bermakna antara banjir yang dialami subjek dengan kejadian infestasi cacing usus.

Berdasarkan hasil yang didapat mengenai faktor-faktor risiko ternyata tidak ditemukan hubungan yang bermakna antara penggunaan sungai dan banjir dengan kejadian infestasi cacing usus. Masih banyak faktor-faktor risiko lain yang berhubungan dengan terjadinya infestasi cacing usus yang tidak diungkap dalam penelitian ini seperti kebiasaan mencuci tangan, kebiasaan memotong kuku, kebiasaan memakai alas kaki, dan lain-lain. Pada penelitian ini kami memang hanya membatasi pada peranan sungai dalam terjadinya infestasi cacing usus. Kelurahan Pesisir merupakan salah satu wilayah di dalam Kota Pekanbaru yang sebagian wilayahnya terletak di sepanjang Sungai Siak, masih banyak wilayah lain yang terletak di pinggir kota dan luar Kota Pekanbaru yang terletak di sepanjang Sungai Siak yang mungkin mempunyai kebiasaan yang berbeda dalam penggunaan sungai yang berhubungan dengan penularan cacing usus. 


\section{KESIMPULAN}

Prevalensi infestasi cacing usus pada anak SD yang tinggal di daerah aliran Sungai Siak Kelurahan Pesisir, Kecamatan Limapuluh, Pekanbaru adalah $36,9 \%$, dengan jenis infestasi terbanyak adalah infestasi campuran dari Ascaris lumbricoides dan Trichuris trichiura (41,67\%), diikuti dengan infestasi tunggal Ascaris lumbricoides (33,33\%), dan Trichuris trichiura (25\%). Intensitas infestasi sebagian besar subjek yang terinfestasi cacing adalah ringan $(83,33 \%)$, diikuti sedang $(16,67 \%)$, dan tidak ada yang tergolong dalam intensitas berat. Pada masyarakat di daerah ini hanya sebagian kecil yang masih menggunakan sungai sebagai sumber air untuk aktivitas sehari-hari. Tidak ditemukan adanya hubungan antara penggunaan sungai sebagai sumber air minum, tempat buang air besar, tempat mandi dan gosok gigi, sumber air mencuci sayur/ lalapan, mencuci alat masak, dan banjir rutin dengan kejadian infestasi cacing usus.

\section{UCAPAN TERIMA KASIH}

Penulis mengucapkan terima kasih kepada Dekan Fakultas Kedokteran Universitas Riau yang telah memberikan dana untuk penelitian ini melalui program Hibah Penelitian Dosen FK Unri. Terima kasih juga kepada Camat dan staf Kecamatan Lima Puluh, Lurah dan staf Kelurahan Pesisir, serta Kepala SDN 003, SDN 010, dan SDN 028 Kelurahan Pesisir yang telah memfasilitasi guna terlaksananya penelitian ini. Tidak lupa kepada murid-murid SD dan orang tuanya yang telah bersedia menjadi sampel dalam penelitian ini.

\section{DAFTAR PUSTAKA}

1. Crompton DWT. How much human helminthiasis is there in the world? Journal of Parasitology 1993;85:397-403.

2. Tjitra E. Penelitian-penelitian "Soil transmitted helminth" di Indonesia. Cermin Dunia Kedokteran 1991;72:13-17.

3. Elmi, Sembiring T, Dewiyani BS, Hamid ED, Pasaribu S, Lubis CP. Status gizi dan infestasi cacing usus pada anak sekolah dasar [Laporan penelitian]. Medan: e-USU Repository;2004.

4. Tadesse G. The prevalence of intestinal helminthic infections and associated risk factors among school children in Babile town, eastern Ethiopia. Ethiop.J.Health Dev. 2005;19(2):140-7.

5. Margono SS. Nematoda usus. Dalam: Gandahusada S, Ilahude HD, Pribadi W, eds. Parasitologi Kedokteran. Edisi ketiga. Jakarta: FKUI; 2000.

6. Depkes. Pedoman pengendalian cacingan.Lampiran Keputusan Menteri Kesehatan Nomor: 424/MENKES/SK/VI/2006, Tanggal :19 Juni 2006. Diunduh dari: http:// www.depkes.go.id/downloads/Kepmenkes/ $\mathrm{Kec}$ acingan $\% 20 \mathrm{dan} \% 20 \mathrm{Filariasis/}$ Lamp\%20KMK\%20Cacingan.DOC, tanggal 20 Februari 2008.

7. Depkes-go.id. Pemberantasan penyakit menular langsung. (diakses tanggal 20 Februari 2008). Diunduh dari: http://www.pppl.depkes.go.id/ images_data/profil\%20P2ML\%202004.pdf

8. Sekartini R, Wawolumaya C, Kesume W, Memy YD, Yulianti, Syihabul S, et al. Pengetahuan, sikap dan prilaku ibu yang memiliki anak usia SD tentang penyakit cacingan di kelurahan Pisangan Baru Jakarta Timur. Medika 2002;10:629-32.

9. Suwarni, Purnomo, Ilahude HD, Harijani. Penelitian parasit usus di sungai Ciliwung. I. Kebiasaan penduduk yang ada kaitannya dengan penularan cacing usus sepanjang sungai Ciliwung. Cermin Dunia Kedokteran 1991;72:5-7.

10.Sari K. Jumlah kasus infeksi Trichuris trichiura pada murid SD Negeri 034 di kelurahan Sri Meranti Kecamatan Rumbai Kota Pekanbaru [Skripsi]. Pekanbaru:FK Unri;2007.

11.Riau-go.id. 47 Persen Siswa SD Cacingan, Pengaruhi Prestasi. 2007 (diakses tanggal 20 Juni 2008). Diunduh dari: http://www.riau.go.id,.

12.Herison R. Infeksi soil transmitted helminths pada murid SD Negeri 027 Labuhan Tangga Besar Kecamatan Bangko Kabupaten Rokan Hilir [Skripsi]. Pekanbaru: FK Unri;2007.

13. Banjar-Jabar go id. Survey Kecacingan di 3 SDN dan 1 MI Kota Banjar. 2007 (diakses tanggal 8 februari 2008). Diunduh dari: http:// www.banjar-jabar.go.id/redesign/,.

14.Rampengan TH, Laurentz. Penyakit infeksi tropik pada anak. Manado:EGC;1992. 